\title{
Analisa Potensi Aliran Lahar Kali Putih, Gunungapi Kelud
}

\author{
Hayu Rahayu $^{1 *}$, Suharyanto ${ }^{2}$, Sri Sangkawati ${ }^{3}$ \\ 1,2,3 Jurusan Teknik Sipil, Universitas Diponegoro \\ E-mail: 1"hayurahayu75@gmail.com, ${ }^{2}$ suharyanto20k@gmail.com, ${ }^{3}$ srisangkawati@gmail.com \\ Received 10 June 2020; Reviewed 31 August 2020; Accepted 19 September 2020 \\ Journal Homepage: http://jurnal.borneo.ac.id/index.php/borneoengineering
}

\begin{abstract}
Kelud Volcano is one of the active volcanoes and located in East Java. After the eruption, Kelud Volcano left a number of volcanic material from the rock, sand and the ash on residential land, plantations and the surrounding area. The main problem is the eruption of Kelud Volcanoes has the potential to experience an increase in the frequency of eruptions and there has been no development of a regional reconstruction model for secondary impacts due to eruptions in the field of water resources infrastructure. Based on these problems, a test of the Sabo and modular hydraulic physical models will be planned. This study discusses the identification of the location and volume of sediments that have the potential to become Kali Putih lava flows from Kelud Volcanoes. The Takahashi analysis method is used to analyze the estimated excess volume of the target sediment which must be controlled by sabo technology. Identification of sediment transport zones is obtained from the classification of slope on existing buildings obtained from satellite imagery. The results of the analysis are as follows: 1.) Sediment transport areas in the Putih Watershed have an area of $863 \mathrm{~km} 2$. 2.) The total volume of Kali Putih sediment that has the potential to become cold lava after eruption is 4,139,414.23 m3. 3.) Sabo and modular hydraulic physical model testing is required. 4) A model of regional reconstruction is needed for secondary impacts due to eruptions in water resources field. 5) New sabo plan planning is needed
\end{abstract}

Keywords: cold lava flow, cold lava volume, sabodam, affected area

\begin{abstract}
Abstrak
Gunungapi Kelud merupakan salah satu gunungapi yang masih aktif dan terletak di Jawa Timur. Pasca erupsi, Gunungapi Kelud menyisakan sejumlah material vulkanik berupa batu, pasir, dan abu dilahan pemukiman, perkebunan dan area sekitarnya. Permasalahan utamanya adalah erupsi Gunungapi Kelud berpotensi mengalami peningkatan frekuensi letusan dan belum adanya pengembangan model rekonstruksi kawasan terhadap dampak sekunder akibat erupsi dalam bidang infrastruktur sumber daya air. Berdasarkan permasalahan tersebut maka akan direncanakan pengujian model fisik hidraulik sabo dan modular. Dalam studi ini dibahas tentang identifikasi lokasi dan volume sedimen yang berpotensi menjadi aliran lahar Kali Putih, Gunungapi Kelud. Metode analisis Takahashi digunakan untuk menganalisis estimasi kelebihan volume sedimen sasaran yang harus dikendalikan oleh teknologi sabo. Identifikasi zona angkutan sedimen didapatkan dari pengklasifikasian kemiringan lereng pada bangunan eksisting yang diperoleh dari citra satelit. Hasil-hasil analisis tersebut adalah sebagai berikut : 1) Daerah transport sedimen pada DAS Putih memiliki luas $863 \mathrm{~km} 2.2)$ Total volume sedimen Kali Putih yang berpotensi menjadi lahar dingin pasca erupsi adalah 4.139.414,23 m3 3) Diperlukan pengujian model fisik hidraulik sabo dan modular 4) Diperlukan model rekonstruksi kawasan terhadap dampak sekunder akibat erupsi dalam bidang infrastruktur sumber daya air 5) Diperlukan perencanaan sabo plan baru.
\end{abstract}

Kata kunci : aliran lahar dingin, volume lahar dingin, sabodam, daerah terdampak 


\section{Pendahuluan}

Gunungapi Kelud, merupakan salah satu gunung api yang masih aktif dan terletak di Jawa Timur. Secara administratif Gunungapi Kelud termasuk dalam 5 wilayah, yaitu Kabupaten Blitar, Kabupaten Kediri, Kabupaten Malang, Kota Blitar dan Kota Kediri. Gunungapi Kelud berdampingan dengan gunung tua, yakni Gunung Kawi- Butak pada sisi timur dan Gunung Anjasmoro pada sisi timur laut (ESDM, 2014). Sedangkan secara geografis Gunungapi Kelud terletak pada $7^{\circ} 56^{\prime}$ LS dan $112^{\circ} 18^{\prime} 30^{\prime}$ ' BT dengan ketinggian puncak 1731 m.dpl, sedangkan tinggi danau kawah 1.113,9 m.dpl dan tinggi dataran Kediri 1650 m.

Gunungapi ini termasuk dalam tipe stratovulkan yang diklasifikasikan sebagai gunungapi aktif tipe A bersifat freato magmatik sampai magmatik dengan karakteristik letusan eksplosif, secara morfologis Gunungapi Kelud ditandai oleh keberadaan bekas kawah yang tumpang tindih yang berbentuk tapal kuda pada bagian tertentu, hal ini menandakan telah terjadi erupsi secara berulang dan bersifat eksplosif (Kadarsetia, 2006). Gunungapi Kelud terbentuk akibat proses subduksi lempeng benua Indo-Australia terhadap lempeng Eurasia.

Pasca erupsi, Gunungapi Kelud menyisakan sejumlah material vulkanik berupa batu, pasir, dan abu dilahan pemukiman, perkebunan dan area sekitarnya. Material-material tersebut apabila bercampur dengan air hujan dalam jumlah besar akan membentuk suatu aliran yang disebut lahar dingin. Tingginya curah hujan dan kondisi lereng yang ada dapat menimbulkan aliran lahar yang memiliki daya rusak tinggi. Untuk mengurangi dampak negatif tersebut, perlu dibuat suatu bangunanbangunan pengendali sedimen (Sabodam) yang diletakkan secara serial pada sungai-sungai yang berpotensi dilalui aliran lahar dingin.

Menurut D.A. Puspitosari, 2011 kapasitas tampungan kantong lahar di daerah Gunungapi Kelud masih cukup besar, dimana kajian tersebut dilakukan sebelum terjadinya erupsi pada tahun 2014. Sedangkan menurut Sutikno hardjisuwarno, dkk, 2012, akibat elevasi $630 \mathrm{~m}$ sampai $318 \mathrm{~m}$ kecepatan rambat banjir sebesar $8,41 \mathrm{~m} / \mathrm{dtk}$ dan terjadi perlambatan rata-rata sebesar 1,59 $\mathrm{m} / \mathrm{dtk}$ pada elevasi $318 \mathrm{~m}$ karena adanya perubahan kemiringan dasar sungai telah menelan banyak korban sehingga diperlikan sistem prakiraan dan peringatan dini aliran debris di DAS Putih. Pada tahun erupsi, menurut Sitti Febriyani, dkk, 2014 kawasan yang mempunyai resiko tinggi setelah letusan yaitu Desa Pandansari, Desa Ngantru dan Desa Pagersari.

Permasalahan utama di sini adalah, aktivitas erupsi Gunungapi Kelud berpotensi mengalami peningkatan frekuensi letusan pada tahun-tahun berikutnya, dan belum adanya pengembangan model rekonstruksi kawasan terhadap dampak sekunder akibat erupsi dalam bidang infrastruktur sumber daya air.

Studi ini dilakukan untuk identifikasi lokasi dan volume sedimen yang berpotensi menjadi aliran lahar di Kali Putih, Gunungapi Kelud, dan terciptanya suatu sistem sabo plan pada Kali Putih yang dapat mengendalikan sedimen lahar secara signifikan dan efektif. Dalam studi ini juga mengidentifikasi lokasi dan volume sedimen yang berpotensi dialiri lahar dingin pasca erupsi.

Lokasi penelitian di kawasan DAS Putih di Kecamatan Garum, Kabupaten Blitar, Jawa Timur. Lokasi studi dapat dilihat pada Gambar 1 dan Gambar 2. 


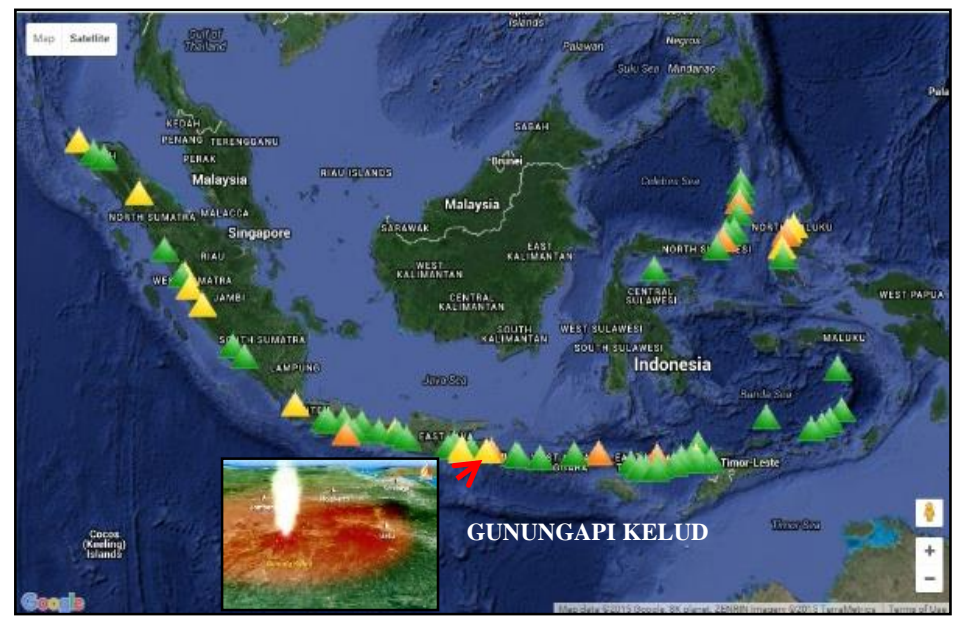

Gambar 1 Peta Lokasi Gunungapi Kelud

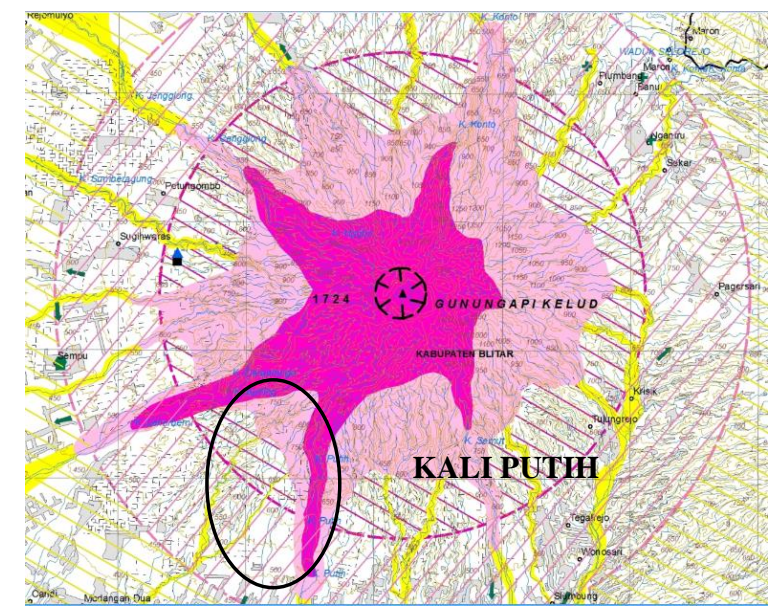

(Sumber: ESDM, 2016)

\section{Gambar 2 Peta Lokasi Kali Putih Gunungapi Kelud}

Dalam penelitian tidak menggunakan pengukuran topografi aktual dan analisis dilakukan untuk sedimen lahar saat ini yang ada pasca erupsi Tahun 2014, tanpa memperhitungkan kemungkinan erupsi baru.

\section{Metode Penelitian}

Lahar merupakan terminologi bahasa Indonesia untuk mendeskripsikan campuran panas atau dingin dari air dan batuan yang mengalir ke bawah di lembah gunung atau lereng sungai (USGS, 2013). Berbeda dengan aliran sedimen biasa, lahar atau dapat disebut juga aliran sedimen merupakan cairan atau fluida khusus dengan perbedaan yang besar pada gradasi sedimen, karakteristik, dan pergerakan dari air bersedimen normal (Pan, et al. 2013).

Sedimen Lahar adalah suatu kepingan atau potongan yang terbentuk oleh proses fisik dan kimia berbentuk batuan atau tanah yang berasal dari muntahan material piroklastik gunungapi dan dapat 
bergerak membentuk aliran lahar serta mengendap disuatu tempat. Bentuk dari material beraneka ragam dan tidak terbatas dari mulai yang berbentuk bulat sampai berbentuk tajam.

\subsection{Zonasi Angkutan Sedimen}

Identifikasi zona angkutan sedimen pada sungai di daerah vulkanik menurut Takahashi dapat dibedakan menjadi 3 (tiga), yaitu: 1) Daerah produksi sedimen, memiliki kemiringan alur sungai $\geq$ $\Theta 15^{\circ}$. 2) Transportasi sedimen, memiliki kemiringan alur sungai antara $10^{\circ}<\Theta<15^{\circ}$. 3) Sedimentasi/pengendapan sedimen $2^{\circ} \leq \Theta<10^{\circ}$. (Takahashi, 2007)

\subsection{Intensitas Hujan Rencana}

Analisis intensitas curah hujan menggunakan rumus yang diberikan oleh DR. Mononobe yaitu: (Soewarno, 1995)

$$
I=(\text { R24 / } 24) \times(24 / t) 2 / 3
$$

dimana:

I = Intensitas Curah Hujan (mm/jam)

R24 = Curah hujan maksimum dalam 1 hari $(\mathrm{mm})$

$\mathrm{t} \quad=$ Lamanya Curah Hujan (jam).

\subsection{Estimasi Jumlah Sedimen Sasaran}

Perhitungan jumlah sedimen sasaran yang harus dikendalikan oleh Teknologi Sabo dapat dihitung menggunakan rumus berikut (Kusumosubroto, 2013)

$$
V T=V S E+V S F+V R S+V R B
$$

Dimana,

$V T=$ Jumlah potensi sedimen $\left(\mathrm{m}^{3}\right)$

$V S E=$ Sedimen hasil erosi lereng/slope erosion $\left(\mathrm{m}^{3}\right)$

$$
V S E=A 1 . a . d 1+A 2 . a . d 2
$$

$V S F=$ Sedimen akibat tebing sungai yang runtuh/slope failure $\left(\mathrm{m}^{3}\right)$

$$
V S F=B . b . R . d
$$

$V R=$ sedimen akibat erosi tebing sungai / riverbank erosion $\left(\mathrm{m}^{3}\right)$

$$
V R S=0,1 H H 2 . L H+0,5 H L . L L
$$

$V R B=$ sedimen yang sudah ada di sepanjang / dasar sungai / sediment amount in riverbed $\left(\mathrm{m}^{3}\right)$

$$
V R B \quad \square d+V a
$$
1991):

Perhitungan volume sedimen terangkut dihitung menggunakan rumus berikut (Takahashi, T, 


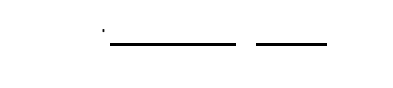

Dimana,

$\mathrm{Vt}=$ Volume sedimen terangkut/transportable $(\mathrm{m} 3)$

$\mathrm{Cd}=$ Konsentrasi sedimen aliran debris

$\mathrm{A}=$ Luas daerah tangkapan sungai $(\mathrm{m} 2)$

Fr $=(0,05 \times(\log \mathrm{A})-2,0) 2+0,05$

$=$ Faktor koreksi run-off aliran debris (nilai $0,1-0,5$ )

R24= Curah hujan maksimum dengan kala ulang (mm)

$\lambda=$ Angka pori (Void ratio) nilai sekitar 0,4

\section{Analisis dan Pembahasan}

\subsection{Identifikasi Zona Angkutan Sedimen}

Menurut Takahashi, zona angkutan sedimen dapat dibagi menjadi 3 bagian berdasarkan kemiringan lerengnya, yaitu daerah produksi sedimen, daerah transport sedimen dan daerah endapan sedimen. Daerah produksi sedimen berada di kemiringan $>15 \sigma$ meliputi puncak gunung. Bagian puncak gunung menghasilkan semburan lahar saat terjadi erupsi dan sebagian besar tertinggal dan menempel pada sisi puncak menjadi lahar dingin. Tingkat kecuraman puncak tersebut menimbulkan potensi keruntuhan lahar dingin yang tinggi, sehingga zona tersebut dikategorikan sebagai daerah produksi sedimen.

Daerah potensi sedimen memiliki potensi bencana diantaranya rawan erosi, longsor dan pergerakan material dalam jumlah besar, rawan longsor tebing sungai dan benturan (impak) bangunan air dan jembatan, rawan limpasan (overtopping) sedimen, benturan (impak) pada bangunan air dan jembatan. Daerah transport sedimen berada pada kemiringan $10 \sigma-15 \sigma$ meliputi lereng gunung. Kemiringan lereng gunung ini sangat ideal untuk aliran debris yang dapat memindahkan sedimen dengan kecepatan yang dipengaruhi oleh gaya grafitasi karena kemiringan lereng dan debit air yang terjadi, sehingga zona ini dikategorikan sebagai daerah transport sedimen. Daerah transport sedimen memiliki potensi bencana rawan longsor tebing sungai dan benturan (impak) bangunan air dan jembatan. Sedangkan daerah endapan sedimen berada - pada kemiringan $2 \sigma-10 \sigma$ meliputi kaki gunung. Kemiringan kaki gunung cenderung landai, didaerah ini pergerakan transportasi sedimen berhenti karena tidak ada lagi pengaruh grafitasi. Sedimen yang terhenti tersebut pada akhirnya akan mengendap, sehingga zona ini dikategorikan sebagai daerah endapan sedimen. Daerah endapan sedimen memiliki potensi bencana rawan limpasan dan pengendapan material boulders, pengendapan material pasir dan pendangkalan alur.

Pengklasifikasian zona angkutan sedimen pada DAS Putih dilakukan menggunakan ArcGis pada setiap letak bangunan sabo kemudian dihitung luasannya. Peta zonasi angkutan sedimen DAS Putih ditampilkan pada Gambar 3. 


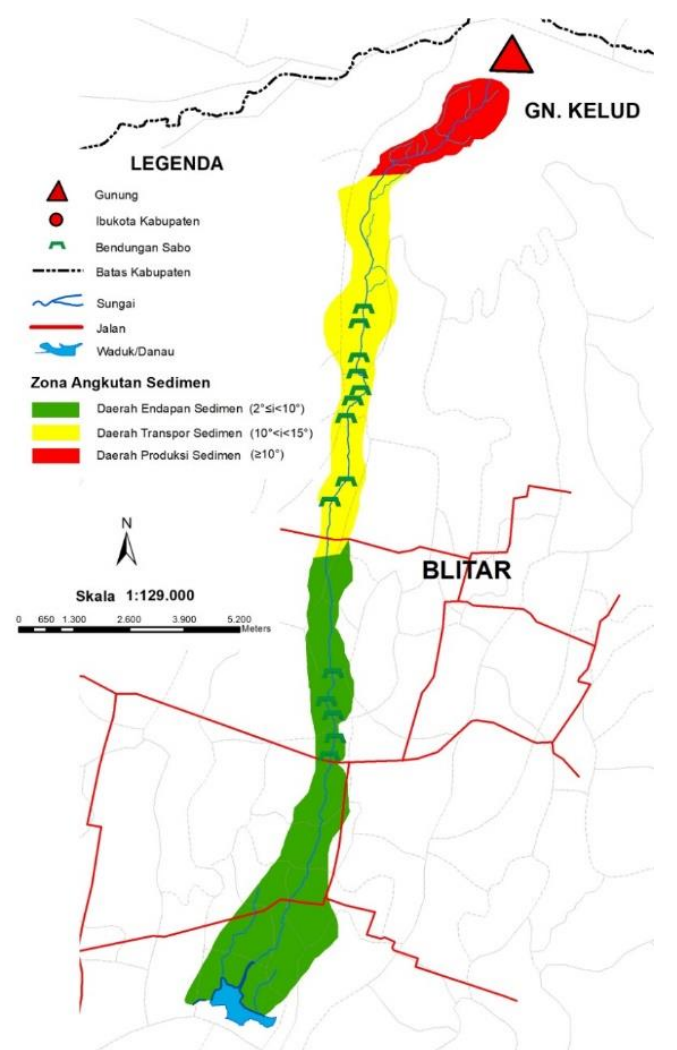

Gambar 3 Zonasi Angkutan Sedimen Sub DAS Putih

DAS Putih dikelompokan berdasarkan kemiringan sungai yang diambil tepat pada posisi bangunan sabo, kemudian dikelompokkan sesuai dengan derajat kemiringannya. Pengelompokan tersebut dapat dilihat pada Tabel 1 berikut:

Tabel 1 Pengelompokan Bangunan Berdasarkan Kemiringan Lokasi di Kali Putih

\begin{tabular}{lcc}
\hline \multicolumn{1}{c}{ Bangunan Sabo } & Kemiringan & Derajat \\
\hline PUCD3 & $>15$ Derajat & 16,56 \\
PUCD4 & $>15$ Derajat & 18 \\
PUCD5 & 10-15 Derajat & 10,8 \\
PUCD6 & $>15$ Derajat & 19,5 \\
PUKD2 & $>15$ Derajat & 19,44 \\
PUKD3 & $>15$ Derajat & 17,54 \\
PUKD4 & $>15$ Derajat & 18,72 \\
PUKD9 & $>15$ Derajat & 23,4 \\
PUKL1 & 2 - 10 Derajat & 4,68 \\
PUSDT1-4KM & 2 - 10 Derajat & 5,4 \\
PUPD6 & 2 - 10 Derajat & 3,6 \\
PUPD5 & 2 - 10 Derajat & 2,88 \\
PUPD7 & 10-15 Derajat & 12,24 \\
PUDP11 & 2 - 10 Derajat & 5,04 \\
PODP12 & $>15$ Derajat & 23,4 \\
PUDP3LD & 10-15 Derajat & 10,04 \\
PUDP3 & 2 - 10 Derajat & 3,6 \\
PUDP2LD & 10-15 Derajat & 10,8 \\
PUDP2TENGAH & $>15$ Derajat & 26,64 \\
PUDP2 & $>15$ Derajat & 17,64 \\
\hline
\end{tabular}




\begin{tabular}{lcc}
\hline \multicolumn{1}{c}{ Bangunan Sabo } & Kemiringan & Derajat \\
\hline PUKL1LD & >15 Derajat & 22,32 \\
PUDP1LD & 2 - 10 Derajat & 3,6 \\
PUDP1 & 2 - 10 Derajat & 7,2 \\
PUKL2 & 2 - 10 Derajat & 4,32 \\
PUKD12 & 10-15 Derajat & 10,44 \\
PUKD13 & 2 - 10 Derajat & 8,64 \\
PUKD1LD & 2 - 10 Derajat & 6,84 \\
PUKD2LD & 2 - 10 Derajat & 3,96 \\
PUKD3LD & 2 - 10 Derajat & 4,32 \\
PU CONFLUENCE & 2 - 10 Derajat & 6,84 \\
\hline
\end{tabular}

Berdasarkan data pengelompokan pada Tabel 1 dibuatlah zona angkutan sedimen DAS Putih. Luas zona angkutan sedimen DAS Putih dapat dilihat pada

Tabel 2 berikut:

Tabel 2 Luas Zona Angkutan Sedimen DAS Putih

\begin{tabular}{rrrr}
\hline NAME & Keterangan $\left.\mathbf{( 0}^{\mathbf{}}\right)$ & Kategori & KM2 \\
\hline DAS Putih & $2-10$ & Daerah Endapan Sedimen & 1437 \\
DAS Putih & $10-15$ & Daerah Transpor Sedimen & 863 \\
DAS Putih & $>15$ & Daerah Produksi Sedimen & 322 \\
\hline
\end{tabular}

\subsection{Perhitungan estimasi kelebihan volume produksi sedimen}

Estimasi kelebihan volume produksi sedimen yang tertransport dihitung menggunakan Rumus Takahashi. Selain sedimen transport perlu dipertimbangkan pula potensi sedimen atau sedimen yield. Sedimen yield adalah suatu massa material yang tidak stabil di daerah sungai, yang apabila mendapat pengaruh eksternal dapat menjadi aliran luruh.

\section{Sedimen Hasil Erosi Lereng (VSE)}

Estimasi sedimen hasil erosi lereng (slope erosion) adalah perhitungan volume erosi lahar dingin pada lereng yang dipengaruhi oleh kemiringan lahan. Estimasi sedimen erosi tebing mengacu pada Error! Reference source not found., membutuhkan data luas lahan progressive, luas lahan normal, nilai rata-rata berdasarkan kemiringan lahan dan estimasi ketebalan erosi. Perhitungan Sedimen Erosi Kali Putih dapat dilihat pada Tabel 3.

Tabel 3 Perhitungan Sedimen Hasil Erosi Lereng (VSE) Kali Putih

\begin{tabular}{lrrrrrrrr}
\hline Bangunan Sabo & L (meter) & $\begin{array}{c}\text { Lahan } \\
\text { Progresive } \\
\text { (M2) }\end{array}$ & $\begin{array}{c}\text { Lahan } \\
\text { Normal } \\
\text { (M2) }\end{array}$ & $\begin{array}{c}\text { व } \\
\text { (Sudut } \\
\text { Lereng) }\end{array}$ & a & d1 & d2 & (VSE) \\
\hline PUCD3 & 574,79 & - & 18,00 & 1,05 & 0,30 & 0,10 & - \\
PUCD4 & 484,58 & - & 16,56 & 1,04 & 0,30 & 0,10 & - \\
PUCD5 & 361,58 & - & 10,80 & 1,02 & 0,30 & 0,10 & - \\
PUCD6 & 371,00 & - & 19,50 & 1,06 & 0,30 & 0,10 & - \\
PUKD2 & 284,11 & - & 19,44 & 1,06 & 0,30 & 0,10 & - \\
PUKD3 & 466,90 & - & 17,54 & 1,05 & 0,30 & 0,10 & - \\
PUKD4 & 898,91 & - & 18,72 & 1,06 & 0,30 & 0,10 & - \\
PUKD9 & 861,00 & - & 23,40 & 1,09 & 0,30 & 0,10 & -
\end{tabular}




\begin{tabular}{|c|c|c|c|c|c|c|c|c|}
\hline Bangunan Sabo & L (meter) & $\begin{array}{c}\text { Lahan } \\
\text { Progresive } \\
\text { (M2) }\end{array}$ & $\begin{array}{c}\text { Lahan } \\
\text { Normal } \\
(\mathrm{M} 2) \\
\end{array}$ & $\begin{array}{c}0 \\
\text { (Sudut } \\
\text { Lereng) }\end{array}$ & $\mathbf{a}$ & d1 & d2 & (VSE) \\
\hline PUKL1 & 743,44 & & - & 23,40 & 1,09 & 0,30 & 0,10 & 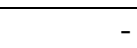 \\
\hline PUSDT1-4KM & $3.350,00$ & 4.000 & - & 5,40 & 1,00 & 0,30 & 0,10 & $1.205,35$ \\
\hline PUPD6 & $3.531,66$ & 4.000 & - & 4,68 & 1,00 & 0,30 & 0,10 & $1.204,01$ \\
\hline PUPD5 & 973,85 & 2.800 & - & 2,88 & 1,00 & 0,30 & 0,10 & 841,06 \\
\hline PUPD7 & 973,85 & 2.800 & - & 3,60 & 1,00 & 0,30 & 0,10 & 841,66 \\
\hline PUDP11 & $1.763,00$ & & - & 5,04 & 1,00 & 0,30 & 0,10 & \\
\hline PODP12 & 911,09 & & - & 12,24 & 1,02 & 0,30 & 0,10 & - \\
\hline PUDP3LD & 621,23 & & - & 10,04 & 1,02 & 0,30 & 0,10 & - \\
\hline PUDP3 & 266,10 & & - & 11,52 & 1,02 & 0,30 & 0,10 & - \\
\hline PUDP2LD & 266,10 & & - & 10,80 & 1,02 & 0,30 & 0,10 & - \\
\hline PUDP2TENGAH & 358,20 & & - & 25,20 & 1,11 & 0,30 & 0,10 & - \\
\hline PUDP2 & 801,72 & & - & 12,24 & 1,02 & 0,30 & 0,10 & - \\
\hline PUKL1LD & 380,45 & & - & 9,36 & 1,01 & 0,30 & 0,10 & - \\
\hline PUDP1LD & 400,00 & & - & 9,00 & 1,01 & 0,30 & 0,10 & - \\
\hline PUDP1 & 292,91 & & - & 19,44 & 1,06 & 0,30 & 0,10 & - \\
\hline PUKL2 & 438,78 & & - & 3,96 & 1,00 & 0,30 & 0,10 & - \\
\hline PUKD12 & $1.498,76$ & & - & 18,72 & 1,06 & 0,30 & 0,10 & - \\
\hline PUKD13 & 606,07 & & - & 9,36 & 1,01 & 0,30 & 0,10 & - \\
\hline PUKD1LD & $4.074,13$ & & - & 5,04 & 1,00 & 0,30 & 0,10 & - \\
\hline PUKD2LD & 668,37 & 6.100 & - & 3,60 & 1,00 & 0,30 & 0,10 & $1.833,62$ \\
\hline PUKD3LD & 363,51 & 800 & - & 1,88 & 1,00 & 0,30 & 0,10 & 240,13 \\
\hline $\begin{array}{l}\text { PU } \\
\text { CONFLUENCE }\end{array}$ & 542,00 & & - & 8,28 & 1,01 & 0,30 & 0,10 & 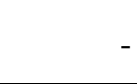 \\
\hline
\end{tabular}

2. Sedimen Akibat Tebing Sungai yang Runtuh (VSF)

Perhitungan sedimen akibat tebing sungai yang runtuh adalah perhitungan volume tebing kanan dan kiri aliran sungai yang runtuh. Sedimen akibat runtuhnya tebing mengacu pada Error! Reference source not found., membutuhkan data luas sub basin, luas sub basin yang berpegunungan, nilai daerah runtuhan dan ketebalan runtuhan. Perhitungan sedimen akibat runtuhnya tebing kali putih dapat dilihat pada Tabel 4.

Tabel 4 Perhitungan Sedimen Akibat Runtuhnya Tebing (VSF) Kali Putih

\begin{tabular}{lrrrrrr}
\hline Bangunan Sabo & L (meter) & \multicolumn{1}{c}{ B (M2) } & \multicolumn{1}{c}{ b (M2) } & R & d & (VSF) \\
\hline PUCD3 & 574,79 & 17.875 .000 & 8.340 .000 & - & 10 & - \\
PUCD4 & 484,58 & 17.436 .000 & 440.000 & - & 10 & - \\
PUCD5 & 361,58 & 17.112 .000 & 330.000 & - & 10 & - \\
PUCD6 & 371,00 & 16.849 .000 & 250.000 & - & 10 & - \\
PUKD2 & 284,11 & 16.638 .000 & 210.000 & - & 10 & - \\
PUKD3 & 466,90 & 16.292 .000 & 340.000 & - & 10 & - \\
PUKD4 & 898,91 & 15.845 .000 & 440.000 & - & 10 & - \\
PUKD9 & 861,00 & 15.132 .000 & 7.100 .000 & - & 10 & - \\
PUKL1 & 743,44 & 14.580 .000 & 550.000 & - & 10 & - \\
PUSDT1-4KM & $3.350,00$ & 12.109 .000 & 2.470 .000 & - & 10 & - \\
PUPD6 & $3.531,66$ & 12.109 .000 & 2.470 .000 & - & 10 & - \\
PUPD5 & 973,85 & 11.504 .000 & 600.000 & - & 10 & - \\
PUPD7 & 973,85 & 11.504 .000 & 600.000 & - & 10 & - \\
PUDP11 & $1.763,00$ & 10.813 .000 & 690.000 & - & 10 & - \\
PODP12 & 911,09 & 10.581 .000 & 230.000 & - & 10 & - \\
PUDP3LD & 621,23 & 10.161 .000 & 410.000 & - & 10 & - \\
PUDP3 & 266,10 & 10.031 .000 & 120.000 & - & 10 & - \\
PUDP2LD & 266,10 & 9.993 .000 & 30.000 & - & 10 & - \\
PUDP2TENGAH & 358,20 & 19.603 .000 & 6.610 .000 & - & 10 & - \\
PUDP2 & 801,72 & 19.038 .000 & 560.000 & - & 10 & -
\end{tabular}




\begin{tabular}{lrcrrrr}
\hline Bangunan Sabo & L (meter) & B (M2) & \multicolumn{1}{c}{ b (M2) } & R & d & (VSF) \\
\hline PUKL1LD & 380,45 & 17.987 .000 & 1.060 .000 & - & 10 & - \\
PUDP1LD & 400,00 & 17.659 .000 & 310.000 & - & 10 & - \\
PUDP1 & 292,91 & 17.366 .000 & 290.000 & - & 10 & - \\
\hline PUKL2 & 438,78 & 17.205 .000 & 160.000 & - & 10 & - \\
PUKD12 & $1.498,76$ & 16.903 .000 & 300.000 & - & 10 & - \\
PUKD13 & 606,07 & 15.726 .000 & 1.170 .000 & - & 10 & - \\
PUKD1LD & $4.074,13$ & 15.271 .000 & 450.000 & - & 10 & - \\
PUKD2LD & 668,37 & 11.901 .000 & 3.370 .000 & - & 10 & - \\
PUKD3LD & 363,51 & 11.220 .000 & 670.000 & - & 10 & - \\
PU & 542,00 & 10.913 .000 & 310.000 & - & 10 & - \\
CONFLUENCE & & & & & &
\end{tabular}

\section{Sedimen Akibat Erosi Tebing Sungai (VRS)}

Perhitungan sedimen akibat erosi tebing sungai (riverbank erosion) adalah perhitungan volume sedimen akibat tergerusnya tepi sungai. Perhitungan sedimen akibat erosi tebing sungai mengacu pada Error! Reference source not found. yang membutuhkan data panjang teras atas dan bawah serta ketebalan tererosinya teras atas dan bawah. Perhitungan sedimen akibat erosi tebing Kali Putih dapat dilihat pada Tabel 5.

Tabel 5 Perhitungan Akibat Erosi Tebing (VSR) Kali Putih

\begin{tabular}{|c|c|c|c|c|}
\hline Bangunan Sabo & L (meter) & $\begin{array}{c}\text { Teras } \\
\text { bawah } \\
\text { (Meter) }\end{array}$ & $\begin{array}{l}\text { Teras atas } \\
\text { (Meter) }\end{array}$ & (VSR) \\
\hline PUCD3 & 574,79 & 36,60 & 13,30 & $87.164,03$ \\
\hline PUCD4 & 484,58 & 20,40 & 13,70 & $29.261,36$ \\
\hline PUCD5 & 361,58 & 4,35 & 1,00 & 720,36 \\
\hline PUCD6 & 371,00 & 2,85 & 2,57 & 546,39 \\
\hline PUKD2 & 284,11 & 1,00 & 0,35 & 31,89 \\
\hline PUKD3 & 466,90 & 1,43 & 0,50 & 107,15 \\
\hline PUKD4 & 898,91 & 1,00 & 0,70 & 133,94 \\
\hline PUKD9 & 861,00 & 1,06 & 0,27 & 103,02 \\
\hline PUKL1 & 743,44 & 2,36 & 0,66 & 446,45 \\
\hline PUSDT1-4KM & $3.350,00$ & 0,30 & 0,06 & 31,36 \\
\hline PUPD6 & $3.531,66$ & 0,36 & 0,15 & 53,72 \\
\hline PUPD5 & 973,85 & 0,12 & 0,06 & 1,75 \\
\hline PUPD7 & 973,85 & 0,13 & 0,02 & 1,68 \\
\hline PUDP11 & $1.763,00$ & 0,09 & 0,06 & 2,06 \\
\hline PODP12 & 911,09 & 0,05 & 0,01 & 0,24 \\
\hline PUDP3LD & 621,23 & 0,48 & 0,15 & 15,71 \\
\hline PUDP3 & 266,10 & 0,35 & 0,15 & 3,86 \\
\hline PUDP2LD & 266,10 & 0,17 & 0,03 & 0,79 \\
\hline PUDP2TENGAH & 358,20 & 18,90 & 20,40 & $27.702,11$ \\
\hline PUDP2 & 801,72 & 37,30 & 23,50 & $155.817,49$ \\
\hline PUKL1LD & 380,45 & 5,39 & 3,00 & $1.447,69$ \\
\hline PUDP1LD & 400,00 & 13,30 & 3,22 & $7.490,34$ \\
\hline PUDP1 & 292,91 & 2,50 & 1,43 & 242,97 \\
\hline PUKL2 & 438,78 & 0,50 & 0,23 & 13,29 \\
\hline PUKD12 & $1.498,76$ & 0,15 & 0,03 & 3,51 \\
\hline PUKD13 & 606,07 & 0,16 & 0,09 & 2,04 \\
\hline PUKD1LD & $4.074,13$ & 1,16 & 0,38 & 607,05 \\
\hline PUKD2LD & 668,37 & 0,32 & 0,11 & 7,65 \\
\hline PUKD3LD & 363,51 & 0,05 & 0,03 & 0,12 \\
\hline $\begin{array}{l}\text { PU } \\
\text { CONFLUENCE }\end{array}$ & 542,00 & 0,07 & 0,04 & 0,35 \\
\hline
\end{tabular}




\section{Sedimen di Dasar Sungai (VRB)}

Perhitungan Sedimen didasar sungai adalah perhitungan volume sedimen yang sudah ada disepanjang dasar sungai. Perhitungan ini mengacu pada Error! Reference source not found. yang membutuhkan data jarak antar cross section, luas potensi sedimen setiap cross section, luas sedimen dasar sungai, ketebalan sedimen dasar sungai, dan lebar dasar sungai. Perhitungan sedimen di dasar sungai Kali Putih dapat dilihat pada Tabel 6.

Tabel 6 Perhitungan Sedimen di Dasar Sungai (VRB) Kali Putih

\begin{tabular}{lrrrrrr}
\hline Bangunan Sabo & $\mathrm{L}$ (meter) & \multicolumn{1}{c}{$\mathrm{w}$} & \multicolumn{1}{c}{$\mathrm{A}$} & $\mathrm{d}$ & \multicolumn{1}{c}{ (Va) } & \multicolumn{1}{c}{$\begin{array}{c}\text { VRB } \\
(1.000 \mathrm{~m} 3)\end{array}$} \\
\hline PUCD3 & 574,79 & 224,00 & $128.752,96$ & 3,69 & 474885,86 & $475.460,65$ \\
PUCD4 & 484,58 & 399,00 & $193.347,42$ & 5,42 & 1047901,1 & $1.048 .385,72$ \\
PUCD5 & 361,58 & 67,10 & $24.262,02$ & 1,65 & 40062,859 & $40.424,44$ \\
PUCD6 & 371,00 & 58,80 & $21.814,80$ & 1,51 & 32986,491 & $33.357,49$ \\
PUKD2 & 284,11 & 27,30 & $7.756,20$ & 0,91 & 7032,1954 & $7.316,31$ \\
PUKD3 & 466,90 & 30,20 & $14.100,38$ & 0,97 & 13674,206 & $14.141,11$ \\
PUKD4 & 898,91 & 23,90 & $21.483,95$ & 0,83 & 17825,678 & $18.724,59$ \\
PUKD9 & 861,00 & 17,00 & $14.637,00$ & 0,66 & 9677,2365 & $10.538,24$ \\
PUKL1 & 743,44 & 58,80 & $43.714,27$ & 1,51 & 66101,016 & $66.844,46$ \\
PUSDT1-4KM & $3.350,00$ & 7,72 & $25.862,00$ & 0,39 & 10101,991 & $13.451,99$ \\
PUPD6 & $3.531,66$ & 7,68 & $27.123,15$ & 0,39 & 10557,982 & $14.089,64$ \\
PUPD5 & 973,85 & 7,40 & $7.206,49$ & 0,38 & 2736,6018 & $3.710,45$ \\
PUPD7 & 973,85 & 7,40 & $7.206,49$ & 0,38 & 2736,6018 & $3.710,45$ \\
PUDP11 & $1.763,00$ & 7,87 & $13.874,81$ & 0,40 & 5489,6358 & $7.252,64$ \\
PODP12 & 911,09 & 6,89 & $6.277,41$ & 0,36 & 2272,968 & $3.184,06$ \\
PUDP3LD & 621,23 & 9,69 & $6.019,72$ & 0,45 & 2736,0585 & $3.357,29$ \\
PUDP3 & 266,10 & 5,77 & $1.535,40$ & 0,32 & 493,93662 & 760,04 \\
PUDP2LD & 266,10 & 7,15 & $1.902,62$ & 0,37 & 706,13588 & 972,24 \\
PUDP2TENGAH & 358,20 & 192,00 & $68.774,40$ & 3,33 & 228890,43 & $229.248,63$ \\
PUDP2 & 801,72 & 218,00 & $174.774,96$ & 3,62 & 633067,77 & $633.869,49$ \\
PUKL1LD & 380,45 & 310,00 & $117.939,50$ & 4,58 & 540215,55 & $540.596,00$ \\
PUDP1LD & 400,00 & 333,00 & $133.200,00$ & 4,80 & 639931,83 & $640.331,83$ \\
PUDP1 & 292,91 & 101,00 & $29.583,91$ & 2,17 & 64160,808 & $64.453,72$ \\
PUKL2 & 438,78 & 7,12 & $3.124,11$ & 0,37 & 1156,2369 & $1.595,02$ \\
PUKD12 & $1.498,76$ & 15,00 & $22.481,40$ & 0,61 & 13673,642 & $15.172,40$ \\
PUKD13 & 606,07 & 8,90 & $5.394,02$ & 0,43 & 2316,5382 & $2.922,61$ \\
PUKD1LD & $4.074,13$ & 47,30 & $192.706,35$ & 1,31 & 252040,38 & $256.114,51$ \\
PUKD2LD & 668,37 & 25,66 & $17.150,37$ & 0,87 & 14920,316 & $15.588,69$ \\
PUKD3LD & 363,51 & 4,50 & $1.635,80$ & 0,27 & 445,86552 & 809,38 \\
PU & 542,00 & 4,30 & $2.330,60$ & 0,26 & 616,2828 & $1.158,28$ \\
CONFLUENCE & & & & & &
\end{tabular}

5. Jumlah Potensi Sedimen (VT)

Perhitungan potensi sedimen (VT) mengacu pada Error! Reference source not found., diperoleh dari hasil penjumlahan sedimen hasil erosi lereng, sedimen akibat tebing sungai yang runtuh, sedimen akibat erosi tebing sungai, dan sedimen yang sudah ada disepanjang dasar sungai. Perhitungan potensi sedimen Kali Putih dapat dilihat pada Tabel 7. 
Tabel 7 Perhitungan Jumlah Potensi Sedimen (VT) Kali Putih

\begin{tabular}{|c|c|c|c|c|c|}
\hline Bangunan Sabo & (VSE) & (VSF) & (VSR) & $(\mathrm{VRB})$ & $\begin{array}{c}\text { Jumlah Potensi } \\
\text { Sedimen (VT) }\end{array}$ \\
\hline PUCD3 & 13537,88737 & 0 & 87164,02955 & 474885,8556 & $575.587,77$ \\
\hline PUCD4 & 20171,41626 & 0 & 29261,3633 & 1047901,137 & $1.097 .333,92$ \\
\hline PUCD5 & 2469,95143 & 0 & 720,357755 & 40062,85858 & $43.253,17$ \\
\hline PUCD6 & 2314,220221 & 0 & 546,38654 & 32986,49105 & $35.847,10$ \\
\hline PUKD2 & 822,5112241 & 0 & 31,8913475 & 7032,195434 & $7.886,60$ \\
\hline PUKD3 & 1478,791783 & 0 & 107,148881 & 13674,20581 & $15.260,15$ \\
\hline PUKD4 & 2268,396943 & 0 & 133,93759 & 17825,67757 & $20.228,01$ \\
\hline PUKD9 & 1594,870741 & 0 & 103,01865 & 9677,236476 & $11.375,13$ \\
\hline PUKL1 & 4763,176428 & 0 & 446,4505888 & 66101,01592 & $71.310,64$ \\
\hline PUSDT1-4KM & 3803,078196 & 0 & 31,356 & 10101,99093 & $13.936,43$ \\
\hline PUPD6 & 3925,402454 & 0 & 53,7165486 & 10557,98206 & $14.537,10$ \\
\hline PUPD5 & 1562,62266 & 0 & 1,75293 & 2736,601757 & $4.300,98$ \\
\hline PUPD7 & 1563,734673 & 0 & 1,6847605 & 2736,601757 & $4.302,02$ \\
\hline PUDP11 & 1392,866366 & 0 & 2,06271 & 5489,6358 & $6.884,56$ \\
\hline PODP12 & 642,3426641 & 0 & 0,2368834 & 2272,967973 & $2.915,55$ \\
\hline PUDP3LD & 611,3336602 & 0 & 15,7109067 & 2736,05852 & $3.363,10$ \\
\hline PUDP3 & 156,6963396 & 0 & 3,85845 & 493,9366249 & 654,49 \\
\hline PUDP2LD & 193,6923236 & 0 & 0,792978 & 706,1358771 & 900,62 \\
\hline PUDP2TENGAH & 7600,833752 & 0 & 27702,1134 & 228890,427 & $264.193,37$ \\
\hline PUDP2 & 17884,03364 & 0 & 155817,4889 & 633067,7749 & $806.769,30$ \\
\hline PUKL1LD & 11953,09416 & 0 & 1447,692145 & 540215,5463 & $553.616,33$ \\
\hline PUDP1LD & 13486,03548 & 0 & 7490,336 & 639931,8322 & $660.908,20$ \\
\hline PUDP1 & 3137,243575 & 0 & 242,9659159 & 64160,8076 & $67.541,02$ \\
\hline PUKL2 & 313,1590252 & 0 & 13,2906462 & 1156,236868 & $1.482,69$ \\
\hline PUKD12 & 2373,713466 & 0 & 3,5070984 & 13673,64159 & $16.050,86$ \\
\hline PUKD13 & 546,6808392 & 0 & 2,0424559 & 2316,538194 & $2.865,26$ \\
\hline PUKD1LD & 19345,4319 & 0 & 607,04537 & 252040,3751 & $271.992,85$ \\
\hline PUKD2LD & 3552,046573 & 0 & 7,6528365 & 14920,31647 & $18.480,02$ \\
\hline PUKD3LD & 403,7968524 & 0 & 0,1235934 & 445,865517 & 849,79 \\
\hline $\begin{array}{l}\text { PU } \\
\text { CONFLUENCE }\end{array}$ & 235,5149802 & 0 & 0,3523 & 616,2827983 & 852,15 \\
\hline
\end{tabular}

6. Sedimen yang Tertransport Takahashi (Vt)

Perhitungan sedimen yang tertransport Takahashi mengacu pada Error! Reference source not found., membutuhkan data curah hujan rencana, luas daerah tangkapan sungai, konsentrasi sedimen aliran debris, faktor koreksi run-off aliran debris, dan angka pori (Void ratio). Curah hujan rencana yang digunakan adalah curah hujan rencana periode 2 tahun mengacu pada Persamaan 1, dapat dilihat pada Tabel 8. Perhitungan sedimen yang tertransport Kali Putih dapat dilihat pada Tabel 9.

Tabel 8 Curah Hujan Rencana (R24)

\begin{tabular}{ccccccccc}
\hline No & $\begin{array}{c}\text { Periode } \\
\text { ulang }\end{array}$ & Peluang & $\log \mathrm{Xr}$ & $\mathrm{S} \log \mathrm{x}$ & $\mathrm{Cs}$ & $\mathrm{k}$ & $\mathrm{Y}=\log (\mathrm{Xt})$ & $\mathrm{Xt}(\mathrm{mm})$ \\
\hline 1 & 2 & 50 & 1,9 & 0,115 & & 0,099 & 1,918 & 83 \\
2 & 5 & 20 & 1,9 & 0,115 & $-0,58$ & 0,877 & 2,008 & 102 \\
3 & 10 & 10 & 1,9 & 0,115 & & 1,224 & 2,048 & 112 \\
4 & 25 & 4 & 1,9 & 0,115 & & 1,554 & 2,086 & 122
\end{tabular}




\begin{tabular}{cccccccc}
5 & 50 & 2 & 1,9 & 0,115 & 1,747 & 2,108 & 128 \\
6 & 100 & 1 & 1,9 & 0,115 & 1,897 & 2,125 & 133 \\
7 & 200 & 0,5 & 1,9 & 0,115 & 2,031 & 2,140 & 138 \\
8 & 1000 & 0,1 & 1,9 & 0,115 & 2,249 & 2,166 & 146 \\
\hline
\end{tabular}

Tabel 9 Perhitungan Sedimen yang Tertransport Takahashi (Vt) Kali Putih

\begin{tabular}{|c|c|c|c|c|c|c|}
\hline Bangunan Sabo & $\mathbf{R 2 4}$ & A (M2) & प & Cd & Fr & Vt (M3) \\
\hline PUCD3 & 83 & 128753 & 0,4 & 0,4 & 0,3 & $3.562 .165 .226,67$ \\
\hline PUCD4 & 83 & 193347,4 & 0,4 & 0,4 & 0,3 & $5.349 .278 .620,00$ \\
\hline PUCD5 & 83 & 24262,02 & 0,4 & 0,4 & 0,3 & $671.249 .164,67$ \\
\hline PUCD6 & 83 & 21814,8 & 0,4 & 0,4 & 0,3 & $603.542 .800,00$ \\
\hline PUKD2 & 83 & 7756,203 & 0,4 & 0,4 & 0,3 & $214.588 .283,00$ \\
\hline PUKD3 & 83 & 14100,38 & 0,4 & 0,4 & 0,3 & $390.110 .513,33$ \\
\hline PUKD4 & 83 & 21483,95 & 0,4 & 0,4 & 0,3 & $594.389 .255,67$ \\
\hline PUKD9 & 83 & 14637 & 0,4 & 0,4 & 0,3 & $404.957 .000,00$ \\
\hline PUKL1 & 83 & 43714,27 & 0,4 & 0,4 & 0,3 & $1.209 .428 .192,00$ \\
\hline PUSDT1-4KM & 83 & 25862 & 0,4 & 0,4 & 0,3 & $715.515 .333,33$ \\
\hline PUPD6 & 83 & 27123,15 & 0,4 & 0,4 & 0,3 & $750.407 .116,80$ \\
\hline PUPD5 & 83 & 7206,49 & 0,4 & 0,4 & 0,3 & $199.379 .556,67$ \\
\hline PUPD7 & 83 & 7206,49 & 0,4 & 0,4 & 0,3 & $199.379 .556,67$ \\
\hline PUDP11 & 83 & 13874,81 & 0,4 & 0,4 & 0,3 & $383.869 .743,33$ \\
\hline PODP12 & 83 & 6277,41 & 0,4 & 0,4 & 0,3 & $173.675 .012,77$ \\
\hline PUDP3LD & 83 & 6019,719 & 0,4 & 0,4 & 0,3 & $166.545 .550,70$ \\
\hline PUDP3 & 83 & 1535,397 & 0,4 & 0,4 & 0,3 & $42.479 .317,00$ \\
\hline PUDP2LD & 83 & 1902,615 & 0,4 & 0,4 & 0,3 & $52.639 .015,00$ \\
\hline PUDP2TENGAH & 83 & 68774,4 & 0,4 & 0,4 & 0,3 & $1.902 .758 .400,00$ \\
\hline PUDP2 & 83 & 174775 & 0,4 & 0,4 & 0,3 & $4.835 .440 .560,00$ \\
\hline PUKL1LD & 83 & 117939,5 & 0,4 & 0,4 & 0,3 & $3.262 .992 .833,33$ \\
\hline PUDP1LD & 83 & 133200 & 0,4 & 0,4 & 0,3 & $3.685 .200 .000,00$ \\
\hline PUDP1 & 83 & 29583,91 & 0,4 & 0,4 & 0,3 & $818.488 .176,67$ \\
\hline PUKL2 & 83 & 3124,114 & 0,4 & 0,4 & 0,3 & $86.433 .809,60$ \\
\hline PUKD12 & 83 & 22481,4 & 0,4 & 0,4 & 0,3 & $621.985 .400,00$ \\
\hline PUKD13 & 83 & 5394,023 & 0,4 & 0,4 & 0,3 & $149.234 .636,33$ \\
\hline PUKD1LD & 83 & 192706,3 & 0,4 & 0,4 & 0,3 & 5.331.542.322,33 \\
\hline PUKD2LD & 83 & 17150,37 & 0,4 & 0,4 & 0,3 & $474.493 .686,20$ \\
\hline PUKD3LD & 83 & 1635,795 & 0,4 & 0,4 & 0,3 & $45.256 .995,00$ \\
\hline $\begin{array}{l}\text { PU } \\
\text { CONFLUENCE }\end{array}$ & 83 & 2330,6 & 0,4 & 0,4 & 0,3 & $64.479 .933,33$ \\
\hline
\end{tabular}

\subsection{Lokasi yang berpotensi dialiri lahar dingin pasca erupsi}

Lokasi yang berpotensi dialiri lahar dingin pasca erupsi yaitu daerah transport sedimen dalam peta zona angkutan sedimen. Daerah transport sedimen pada DAS Putih memiliki luas $863 \mathrm{~km}^{2}$. Daerah ini memiliki potensi bencana rawan longsor tebing sungai dan benturan (impak) bangunan air dan jembatan. Direkomendasikan perencanaan saboplan baru disepanjang zona ini, mengingat hasil analisis diatas yang menunjukkan bahwa saboplan eksisting tidak mampu menampung potensi aliran lahar dingin. Lokasi transport lahar dingin pada DAS Putih ditampilkan pada Gambar 4. 


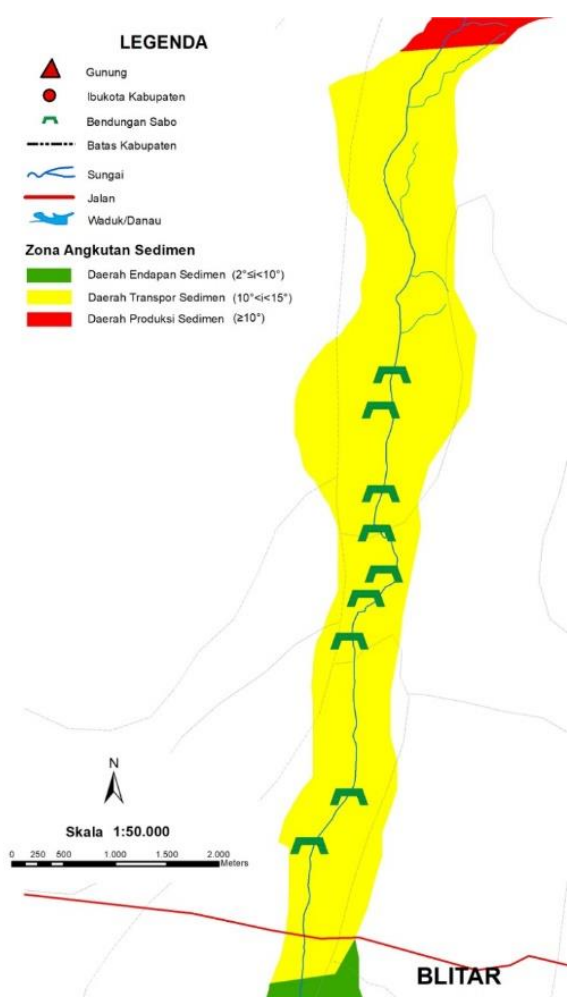

\section{Gambar 4 Lokasi Transport Lahar Dingin Kali Putih}

\subsection{Volume sedimen yang berpotensi menjadi aliran lahar pasca erupsi}

Total volume sedimen Kali Putih yang berpotensi menjadi lahar dingin pasca erupsi yaitu $4,139,414.23 \mathrm{~m}^{3}$. Jumlah potensi sedimen masing-masing bangunan sabo di Kali Putih dapat dilihat pada Tabel 10 .

Tabel 10 Volume Sedimen yang Berpotensi Menjadi Aliran Lahar Dingin Kali Putih

\begin{tabular}{cccc}
\hline Bangunan Sabo & $\begin{array}{c}\text { Jumlah Potensi } \\
\text { Sedimen (VT) }\end{array}$ & Bangunan Sabo & $\begin{array}{c}\text { Jumlah Potensi } \\
\text { Sedimen (VT) }\end{array}$ \\
\hline PUCD3 & $575.587,77$ & PUDP3LD & $3.363,10$ \\
PUCD4 & $1.097 .333,92$ & PUDP3 & 654,49 \\
PUCD5 & $43.253,17$ & PUDP2LD & 900,62 \\
PUCD6 & $35.847,10$ & PUDP2TENGAH & $264.193,37$ \\
PUKD2 & $7.886,60$ & PUDP2 & $806.769,30$ \\
PUKD3 & $15.260,15$ & PUKL1LD & $553.616,33$ \\
PUKD4 & $20.228,01$ & PUDP1LD & $660.908,20$ \\
PUKD9 & $11.375,13$ & PUDP1 & $67.541,02$ \\
PUKL1 & $71.310,64$ & PUKL2 & $1.482,69$ \\
PUSDT1-4KM & $13.936,43$ & PUKD12 & $16.050,86$ \\
PUPD6 & $14.537,10$ & PUKD13 & $2.865,26$ \\
PUPD5 & $4.300,98$ & PUKD1LD & $271.992,85$ \\
PUPD7 & $4.302,02$ & PUKD2LD & $18.480,02$ \\
PUDP11 & $6.884,56$ & PUKD3LD & 849,79 \\
PODP12 & $2.915,55$ & PU CONFLUENCE & 852,15 \\
\hline
\end{tabular}




\section{Kesimpulan}

Dari hasil analisis disimpulkan bahwa kondisi sabo plan dilapangan membutuhkan pengujian model fisik hidraulik sabo dan modular, diperlukan model rekonstruksi kawasan terhadap dampak sekunder akibat erupsi dalam bidang infrastruktur sumber daya air serta diperlukan perbaikan dan perencanaan sabo plan baru mengingat volume sedimen lahar dingin yang dapat ditampung oleh bangunan sabo masih sebagian kecil dari volume sedimen yang tertransport berdasarkan hasil perhitungan takahashi.

\section{Daftar Pustaka}

Argitalia, F.K., (2012), Pengaruh Perubahan Digital Elevation Model (DEM) dalam Simulasi Banjir dengan Software SIMLAR V.1.0 (Studi Kasus Banjir Bandang di Kali Putih, Kabupaten Jember Tahun 2006), Tugas Akhir Jurusan Teknik Sipil dan Lingkungan, Universitas Gadjah Mada,Yogyakarta.

D.A. Puspitosari, (2011). Kantong Lahar sebagai Bangunan Sabo Andalan untuk Menanggulangi Bencana Banjir Lahar di Daerah Gunungapi Kelud.

ESDM, Gunung Kelud. (2014). https://vsi.esdm.go.id/index.php/gunungapi/data-dasargunungapi/538-g-kelud/ (accessed May 17, 2017).

ESDM, Pusat Vulkanologi dan Mitigasi Bencana. Sebaran Gunungapi. 2017. http://www.vsi.esdm.go.id/ (accessed September 17, 2017).

Kadarsetia, Eka et all. 2006. "Karakteristik Kimiawi Air Danau Kawah Gunung Api Kelud, Jawa Timur Pasca Letusan Tahun 1990". Jurnal Geologi Indonesia, Vol. 1 No. 4.

Kusumosubroto, H. (2013), Aliran Debris dan Lahar, Jilid I, Edisi I, Graha Ilmu, Yogyakarta.

Pan, Huali, Ren Wang, Jiangcheng Huang, Guoqiang ou. "Study on The Ultimate Depth of Scour Pit Downstream of Debris Flow Sabo Dam based on The Energy Method." Engineering Geology, 2013: doi:10.1016/j.enggeo.2013.03.026.

PUPR. (2017). RMP Pengembangan Rekonstruksi Balai Litbang Sabo. Yogyakarta.

Rancangan Pedoman Manajamen Penanggulangan Bencana Banjir Bandang. 2012.

Republik Indonesia. Sekretariat Negara RI. 2007.Undang Undang Republik Indonesia No.24 Tahun 2007 Tentang Penanggulangan Bencana, Sekretariat Negara.Jakarta.

Sitti Febriyani Syiko, Turniningtyas Ayu Rachmawati, Arief Rachmansyah, 2014. Analisis Resiko Bencana Sebelum dan Setelah Letusan Gunung Kelud Tahun 2014 (Studi kasus di Kecamatan Ngantang, Malang).

Soewarno. 1995. Hidrologi, Aplikasi metode statistic untuk Analisa jilid I, Penerbid Nova, Bandung

Sutikno Hardjosuwarno, Adam Pamudji Rahardjo, Jazanul Ikhsan, Oriza Andamari, Yanuar Tri Kurniawan, 2012. Pengembangan Sistem Prakiraan dan Peringatan Dini Aliran Debris Di Kali Putih, Kabupaten Jember.

Takahashi, T. Debris Flow: Mechanics, Prediction, and Countermeasures. London, UK: Routledge Taylor \& Francis Group, 2007.

USGS. "Lahars and Theirs Effects." Februari 21, 2013. http://volcanoes.usgs.gov/hazards/lahar/ (accessed Agustus 8, 2015). 